\title{
Fishing strategies and the Ecosystem Approach to Fisheries in the eastern Mediterranean Sea
}

\author{
Christos D. Maravelias, John Haralabous, Efthymia V. Tsitsika \\ Hellenic Centre for Marine Research (HCMR), 46.7 Km Athens-Sounio, P.O Box 712, 19013 Anavissos, Attica Greece. \\ E-mail: cmaravel@hcmr.gr
}

\begin{abstract}
Summary: The sustainable use of aquatic living resources is the cornerstone of the ecosystem approach to fisheries management (EAF). Excess fishing effort leading to the degradation of fishery resources and significant economic waste is globally recognized by resource managers as a major problem for the implementation of the EAF and European's Union Common Fisheries Policy (CFP). Knowledge of how fishers allocate their fishing effort in space and time is essential to understand how a fishery develops. Understanding fishing strategies is also vital for predicting how a fishery might respond to proposed management changes such as effort/area restrictions and introduction of a marine protected area, and for drawing up a management policy. Random utility models were used to examine the factors affecting fishers' behaviour in the NE Mediterranean. The probability of selecting a specific fishing rectangle was estimated using monthly purse seine data. The predictive inputs concerned both subjective behavioural and objective seasonal and technical-economic characteristics. The present study provided direct evidence of the important role that the strategic decision-making behaviour of fishers could play in understanding the way the industry will respond to changes in resource availability, market conditions and management measures under the EAF principle.
\end{abstract}

Keywords: ecosystem approach; random utility model (RUM); discrete choice model; fleet dynamics; fishers behaviour.

Estrategias de pesca y Aproximación Ecosistémica de Pesquerías en el Mediterráneo oriental

Resumen: El uso sostenible de los recursos vivos acuáticos es la piedra angular del enfoque ecosistémico en la gestión de pesquerías (EAF). El exceso de esfuerzo pesquero, responsable de la degradación de los recursos pesqueros y pérdidas econocómicas significativas, es generalmente reconocido por los gestores pesqueros como el principal problema para la implementación del EAF y de la Política Pesquera Común Europea (PPC). El conocimiento de la forma en la que los pescadores localizan su esfuerzo pesquero en espacio y tiempo es esencial para comprender como se desarrolla una pesquería. Entender las estrategias pesqueras es vital también para predecir como una pesquería puede responder en función de cambios de gestión propuestos como restricciones esfuerzo/área, introducción de Áreas Marinas Protegidas (MPA) y en la aplicación de la política de gestión. Para examinar los factores que afectan el comportamiento de la elección de los pescadores del Mediterráneo oriental se han utilizado Modelos de Utilidad Aleatorios (RUMs). La probabilidad de seleccionar un rectángulo específico de pesca fue estimada utilizando datos mensuales de cerqueros. Los datos predictivos de entrada incluían ambos comportamientos, tanto subjetivos como objetivos, estacionales y características técnico-económicas. El presente estudio proporciona indicios claros de la importancia que puede tener la estrategia en la toma de decisiones de los pescadores en la forma en que la industria responderá a los cambios en la disponibilidad de los recursos, condiciones del mercado y medidas de gestión basadas en el principio del EAF.

Palabras clave: enfóque ecosistémico; Modelo de Utilidad Aleatorio; modelo de elección discreta; dinámica de la flota; comportamiento de los pescadores.

Citation/Como citar este artículo: Maravelias C.D., Haralabous J., Tsitsika E.V. 2014. Fishing strategies and the Ecosystem Approach to Fisheries in the eastern Mediterranean Sea. In: Lleonart J., Maynou F. (eds), The Ecosystem Approach to Fisheries in the Mediterranean and Black Seas. Sci. Mar. 78S1: 77-85. doi: http://dx.doi.org/10.3989/scimar.04026.24A

Editors: Jordi Lleonart and Francesc Maynou.

Received: November 11, 2013. Accepted: January 10, 2014. Published: March 28, 2014.

Copyright: () 2014 CSIC. This is an open-access article distributed under the Creative Commons Attribution-Non Commercial Lisence (by-nc) Spain 3.0. 


\section{INTRODUCTION}

The Mediterranean Sea is considered to be one of the most interesting semi-enclosed seas because of the great range of processes and interactions occurring within it. The NE Mediterranean, i.e. the Aegean Sea, is dominated by major basin and sub-basin features such as gyres, jets, eddies and meandering currents, reflecting its complex geometry and bathymetry and the highly variable atmospheric forcing. The Mediterranean fisheries are extremely diverse, targeting a great number of species, and have an extensive scope of fishing gear and methods. Catches are highly multispecific and fishing is a major economic activity in terms of jobs, revenues and food supply (Maravelias et al. 2011). Catches of many species peaked in the late 1980s and early 1990s and have declined since. Although fishing in the Mediterranean has not undergone any dramatic event, some symptoms of overfishing are evident for the most important commercial species.

The overarching principles of the ecosystem approach to fisheries (EAF) are an extension of the conventional principles for sustainable fisheries development to cover the ecosystem as a whole. They aim to ensure that, despite variability, uncertainty and likely natural changes in the ecosystem, the capacity of the aquatic ecosystems to produce fish food, revenues, employment and other essential services and livelihood is maintained indefinitely for the benefit of present and future generations (FAO 2003). The sustainable use of the aquatic living resources is a cornerstone of the EAF. To achieve it, the major challenge is the matching of the fish stocks' productivity with the harvesting capacity of the fishing fleet; a long-pursued goal of the European Union's Common Fisheries Policy (CFP). In the Mediterranean Sea, the management of fishing effort (spatial or/and temporal) alongside technical measures is the main tool responsible for delivering sustainable fisheries. Knowledge of how fishers allocate their fishing effort in space and time is essential to understand how a fishery develops. A number of studies have looked at behavioural aspects of the way fishers allocate their effort spatially (Rijnsdorp et al.
2000, Hilborn et al. 2005, Hutton et al. 2004, Smith et al. 2009, Tidd et al. 2012). The behaviour of fishers can be studied in the short term (their tactics), for example on a trip-by-trip basis in terms of decisions where to fish and which species to target, or in the long term (their strategies), i.e. choices made year by year in which the availability of decommissioning grants, stock status, catch quotas, investment, and other key factors play a critical role in the decision of a fisher to invest in the fishing operation (Tidd et al. 2011). Understanding fishing strategies is vital for predicting how a fishery might respond to proposed management changes under the EAF and CFP, such as the establishment of a marine protected area (MPA) or a simpler temporal or spatial effort ban, and for drawing up a management policy (Andersen et al. 2010, Wilen et al. 2002, Smith and Wilen 2003). The idea behind this work was to understand how the fishery will respond to a likely implementation of a spatial and/or temporal effort restriction under the EAF principle. The fishers' behaviour and their decision choice for fishing among alternative fishing areas was analysed using utility theory. This study was based on the idea put forward by Gordon (1954) that fishers will redistribute fishing effort across fisheries when an expected economic return differs across them. Seeking more profitable grounds, the fishermen may behave as "utility" maximizers and a random utility model (RUM), which originated in the field of econometrics, was used as a tool for understanding this behaviour (Pradham and Leung 2004). Here, we examined whether tactical behaviour by fishers is influenced by previous catch rates, habitual seasonal fishing patterns, experience and expected revenues and whether there are dynamic changes in the relative importance of these drivers through time.

\section{Data}

The study area used here as an example was the Thermaikos Gulf in the northwestern Aegean Sea (Fig. 1). Pelagic trawling is prohibited in Greece, so purse seining is the main fishing method for pelagic species. The target species are anchovy (Engraulis encrasicolus),

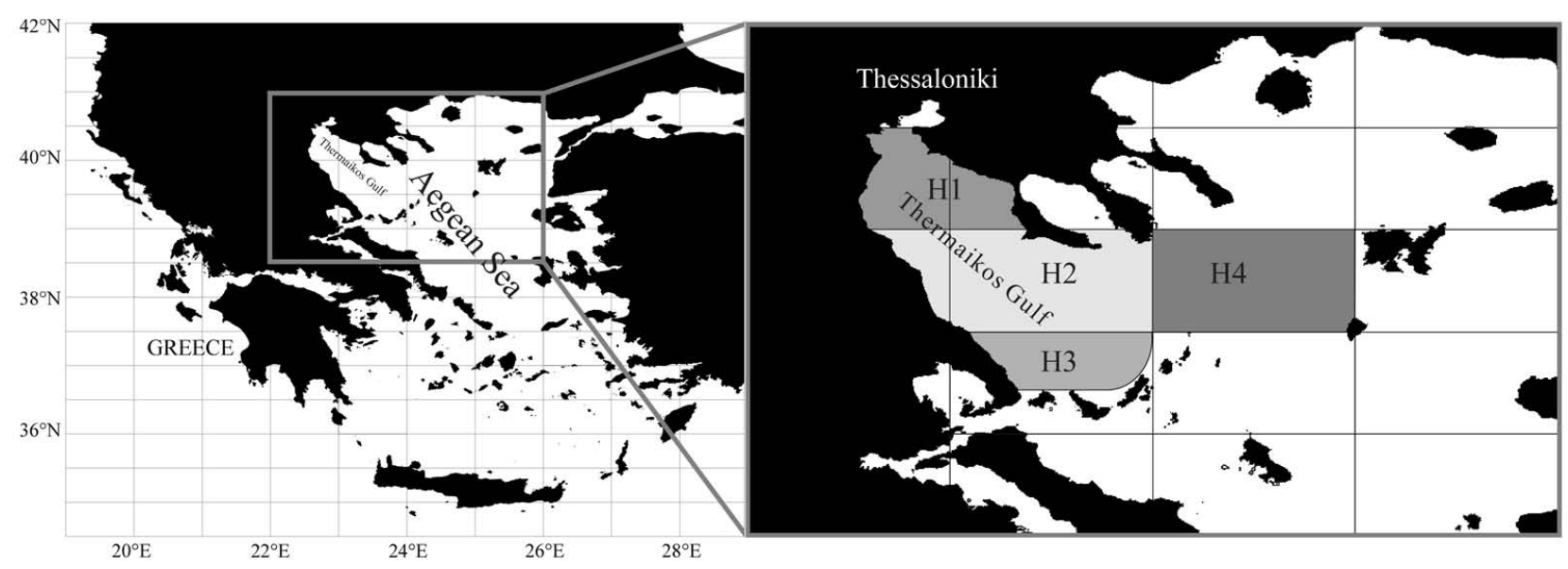

Fig. 1. - Map of the study area in the northwestern Aegean Sea, Thermaikos Gulf, indicating the location of the four studied rectangles, H1, $\mathrm{H} 2, \mathrm{H} 3$ and $\mathrm{H} 4$. 
Table 1. - Field description of the variables calculated for the multinomial logit analysis.

\begin{tabular}{|c|c|}
\hline Field & Description \\
\hline \multicolumn{2}{|c|}{ Basic background information } \\
\hline DAT & Date \\
\hline YEAR & Year \\
\hline MON & Month \\
\hline RECT & Fishing rectangle \\
\hline DTIM & Departure time \\
\hline LTIM & Landing time \\
\hline VE_LEN & Vessel length (m) \\
\hline VE_HP & Vessel horsepower $(\mathrm{hp})$ \\
\hline VE_TON & Vessel tonnage (grt) \\
\hline \multicolumn{2}{|c|}{ Species and fishery information } \\
\hline Ane & Trip's anchovy catch $(\mathrm{kg})$ \\
\hline Sar & Trip's sardine catch $(\mathrm{kg})$ \\
\hline Mac & Trip's mackerel catch $(\mathrm{kg})$ \\
\hline Oth & Trip's other catch $(\mathrm{kg})$ \\
\hline Catch & Trip's total catch (kg) \\
\hline V_ane & Trip's value of anchovy catch $(€)$ \\
\hline V_sar & Trip's value of sardine catch $(€)$ \\
\hline V_mac & Trip's value of mackerel catch $(€)$ \\
\hline V_oth & Trip's value of other catch $(€)$ \\
\hline Value & Trip's value of total catch $(€)$ \\
\hline Pri_ane & Price of anchovy $(€ / \mathrm{kg})$ \\
\hline Pri_sar & Price of sardine $(€ / \mathrm{kg})$ \\
\hline Pri_mac & Price of mackerel $(€ / \mathrm{kg})$ \\
\hline Pri_oth & Price of others $(€ / \mathrm{kg})$ \\
\hline Lag1_pr_ane & Price of anchovy 1 month ago $(€ / \mathrm{kg})$ \\
\hline Lag 12 _pr_ane & Price of anchovy 1 year ago $(€ / \mathrm{kg})$ \\
\hline Mo_catch & Total catch of the month from all rectangles $(\mathrm{kg})$ \\
\hline Mo_val & Value of total monthly catch from all rectangles $(€)$ \\
\hline Fo_eff & Effort of the month in all rectangles (vessel-days) \\
\hline Lag1_yes & Yes if the vessel visited the same rectangle 1 month ago (binary variable) \\
\hline Lag 12 yes & Yes if the vessel visited the same rectangle 12 months ago (binary variable) \\
\hline Lag1_Catch & Trip's total catch for the same rectangle 1 month ago $(\mathrm{kg})$ \\
\hline Lag1_Val & Trip's total value of the catch for the same rectangle 1 month ago $(€)$ \\
\hline Lag12_Catch & Trip's total catch for the same rectangle 1 year ago $(\mathrm{kg})$ \\
\hline Lag12 Val & Trip's total value of the catch for the same rectangle 1 year ago $(€)$ \\
\hline
\end{tabular}

sardine (Sardina pilchardus) and mackerel (Trachurus trachurus and T. mediterraneus). Other species caught by the purse seiners are bogue (Boops boops), round sardinella (Sardinella aurita), Atlantic mackerel (Scomber scombrus), salema (Sarpa salpa), European sprat (Sprattus sprattus) and bluefish (Pomatomus saltatrix). Purse seining is one of the most important fishing methods in the Mediterranean Sea. Fishing operations are carried out exclusively during night hours (from 20:00 to 05:00) with each vessel employing 5-10 persons. The fish are attracted to the upper water column by means of lamps scattered on the surface and finally caught by the encircling net. All vessels conduct daily trips. Management regulations currently in force for the purse seine fishery include mesh size regulations $(>14 \mathrm{~mm})$ and technical measures such as closed seasons (from December to February), closed areas and fishing prohibitions within specific distances from the coast $(100 \mathrm{~m})$. Landings of the purse seine fishery of fleet segments 12-24 m and 24-40 m operating in the EU Aegean Sea were analysed. Monthly data were available for the whole fishing period (March to November) for the years 2000 to 2004.

For this period a total of 245 questionnaire answers were obtained regarding two categories of variables (Table 1 and 2). The first category (Table 1) included two sets of variables: a) the basic background information (date of interview, year, month, fishing rectangle, departure and landing time), vessel characteristics (total length [m], engine power [hp] and tonnage $[\mathrm{t}]$ ); and $\mathrm{b}$ ) the species and fishery infor- mation (price $[€ / \mathrm{kg}]$, catch $[\mathrm{kg}]$ and value $[€]$ of main target species (anchovy, sardine and mackerel) and other species in the catch, total monthly catch and its corresponding price value and fishing effort (vesseldays). The experience of the skipper in terms of previous catches and revenues from a fishing ground was also used as previously known information available at the time of a fishing trip (considered a proxy of expected revenue and catches perceived by fishers from past experience on monthly and annual time-scales). The second category included the alternative choices regarding the reasons for fishing trip start and end as well as the reasons for selecting a specific fishing ground (Table 2). The alternative answers to each of the above three choices for trip start were i) others go out now (others); ii) experience (own); iii) routine/ habits (routine); and iv) weather (weather). The answers for trip end were i) best price/freshness (price); ii) various problems (problems); and iii) tradition (tradition). The answeres for fishing ground choice were i) closeness to harbour and weather conditions (harbour); ii) presence or absence of others (others); and iii) own experience (own). Four fishing rectangles were studied (H1 to H4, Fig. 1).

\section{Random utility modelling with multinomial logit}

A random utility approach (McFadden 1973) was used to model area choice behaviour. The fishing fleet faces a set of available rectangles as alternative choices 
Table 2. - Description of fishers' choice alternative responses included in the multinomial logit analysis. The finally merged responses are given in the last column.

\begin{tabular}{|c|c|c|c|}
\hline Field & Responses & Description of responses & Merged responses \\
\hline \multicolumn{4}{|c|}{$\begin{array}{c}\text { Choice of the fishing trip start } \\
\text { OTHERS }\end{array}$} \\
\hline & $\begin{array}{l}\text { EXPERIENCE } \\
\text { OWN }\end{array}$ & $\begin{array}{l}\text { We have good experience from going out at this time } \\
\text { For our own reasons }\end{array}$ & OWN \\
\hline & $\begin{array}{l}\text { ROUTINE } \\
\text { WEATHER }\end{array}$ & $\begin{array}{l}\text { Because of routine and habits } \\
\text { Because of the weather }\end{array}$ & $\begin{array}{l}\text { ROUTINE } \\
\text { WEATHER }\end{array}$ \\
\hline \multicolumn{2}{|c|}{ Choice of the fishing trip end } & Because of the best fish freshness and price & PRICE \\
\hline & $\begin{array}{l}\text { WEATHER } \\
\text { TECHNICAL } \\
\text { LOW } \\
\text { HOLD }\end{array}$ & $\begin{array}{l}\text { Because of the weather } \\
\text { Because of technical problems } \\
\text { Because the catch rate is low } \\
\text { Because the hold is full }\end{array}$ & PROBLEMS \\
\hline & TRADITION & Because it is the regular trip duration (traditional) & TRADITION \\
\hline Choic & $\begin{array}{l}\text { f fishing ground } \\
\text { HARBOUR } \\
\text { WEATHER }\end{array}$ & $\begin{array}{l}\text { It is very close to the landing harbour } \\
\text { Because of the weather }\end{array}$ & HARBOUR \\
\hline & $\begin{array}{l}\text { OTHERS } \\
\text { CROWD }\end{array}$ & $\begin{array}{l}\text { We have received good signs from others who have been there (on the VHF, etc.) } \\
\text { It is our experience that this ground is less crowded at this time of the year }\end{array}$ & OTHERS \\
\hline & OWN & It is our experience that it is a good place in this season & OWN \\
\hline
\end{tabular}

$\boldsymbol{J} \in(j=1, \ldots, J)$. It is assumed that in each rectangle a measurable utility was obtained. This utility, in the context of econometrics, is a measure of the relative satisfaction gained from a good, a service or an activity that is determined by observable and unobservable characteristics. The random utility function for each choice is represented (Greene 2000) as

$$
U_{j}=V_{j}+\varepsilon_{j}
$$

where $V_{j}$ is a deterministic utility function and $\varepsilon_{j}$ is an unobserved random variable.

The choice for each vessel is to define $U_{j}^{\max }$, the maximum utility among $J$ alternatives. Under this framework, each vessel has a higher likelihood of choosing alternative $j$ over all alternatives if and only if

$$
P_{j}=\operatorname{Prob}\left\{V_{j}+\varepsilon_{j}>V_{k}+\varepsilon_{k} ; k \neq j ; \forall k, j \in J\right\}
$$

Since $\varepsilon_{j}$ and $\varepsilon_{k}$ are random variables, $\varepsilon_{j}-\varepsilon_{k}$ is also a random variable. An important characteristic that should be met in these models is that if alternative $j$ is chosen, $\operatorname{Prob}\left(V_{j}-V_{k}\right)>\operatorname{Prob}\left(\varepsilon_{k}-\varepsilon_{j}\right)$, which means that what it is observed is more influential than what it is not observed. Hence, let $H_{i}$ be a random variable which stands for the rectangle choice made, according to McFadden (1973); if the $J$ alternatives are independent and identically distributed and belong to a Weibull distribution (with parameters lambda, $k$ ), then:

$$
\operatorname{Prob}\left(H_{i}=j\right)=\frac{e^{\beta^{\prime} Z_{i j}}}{\sum_{j=1}^{J} e^{\beta^{\prime} Z_{i j}}}
$$

where $\beta$ are the parameters of the variables $(Z)$ of the utility functions (1).

Since in our case the independent variables were not choice-specific but individual-specific attributes and since we have a polytomous nominal response (the four rectangles), it was preferred to use the multinomial (unordered) logit model (Prellezo et al. 2009). In this case, for $J$ alternatives, only $J-1$ distinct parameter vectors may be identified. Hence, to estimate the utility function and to derive the probability of an alternative $j$ the formula that must be used is:

$$
\operatorname{Prob}\left(H_{i}=j\right)=\frac{e^{\beta^{\prime} Z_{i j}}}{1+\sum_{j=1}^{J-1} e^{\beta^{\prime} Z_{i j}}}
$$

The probability of the reference category can be computed by taking into account that the summation of the probabilities should be equal to one. The utility function (1) was estimated iteratively using a multinomial logit model, converging to the maximum likelihood result. The model made the assumption known as the independence of irrelevant alternatives (IIA) (Cox and Snell 1989). The model fitting and its sensitivity analysis was implemented using SPSS for Windows (NOMREG procedure, SPSS 2003) and the VGAM library in $\mathrm{R}$ language (R Development Core Team 2008).

\section{RESULTS}

\section{Exploratory data analysis}

The mean purse seine catches per vessel-day for the period 2000-2004 vary from rectangle to rectangle regarding species composition and biomass (Fig. 2, left). Anchovy and sardine are mainly caught in rectangles $\mathrm{H} 2$ and $\mathrm{H} 3$ and have negligible presence in $\mathrm{H} 1$, while mackerel and the other species can be found in all rectangles.

The seasonality observed in the species composition of the catches (Fig. 2, right), depends on anchovy's behaviour because it is the main target species from March to June in almost all rectangles. Sardine is mainly caught from March to May and a preference in rectangle $\mathrm{H} 4$ is obvious in April. After July the rest of the species become the main target but they exhibit lower total catches. The majority of choice selections in all questions (Fig. 3) expressed personal experience 

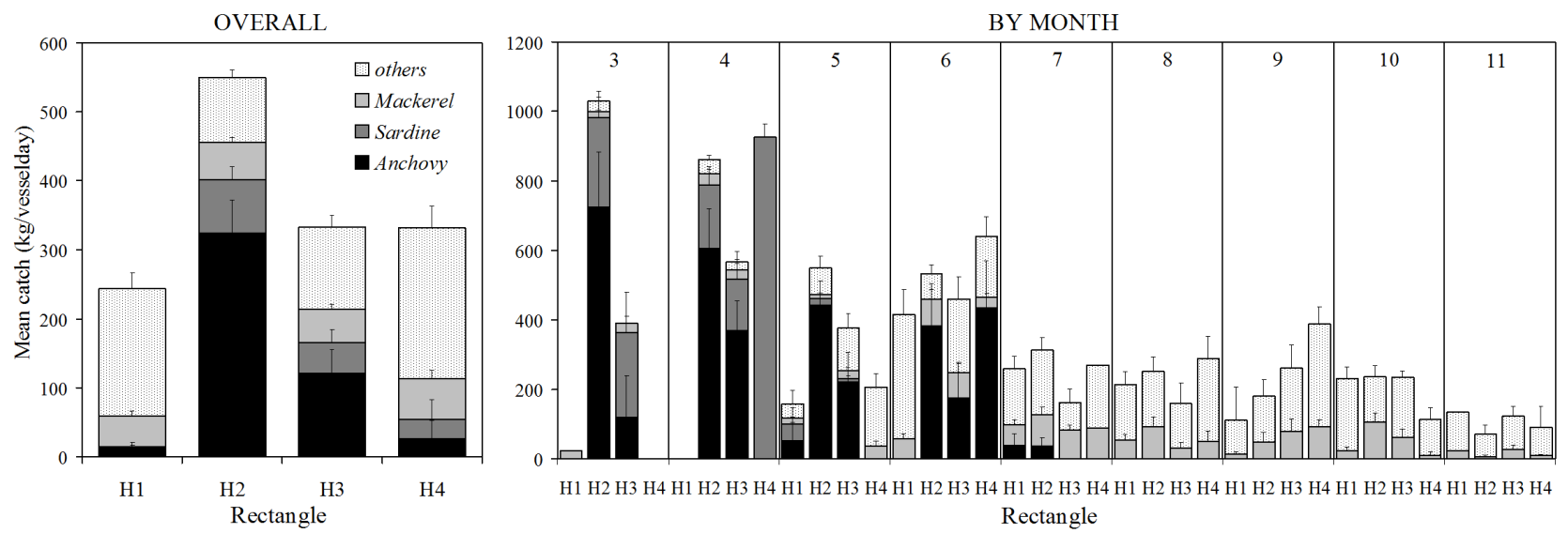

Fig. 2. - Mean purse seine catches by species (in kg per vessel-day) per studied rectangle for the period 2000-2004. Left, average from all months; right, averages by month. The error bars in the graph represent the standard errors (se) of the means.

coded as "Routine", "Tradition", or "Own". An interesting proportion of choices (16-26\%) were attributed to other fishers" practice coded as "Others".

Figure 4 shows the actual mean total purse seine catches (2000-2004) achieved by various combinations of choices. The "Routine", "Tradition" and "Own" combinations of choices gave the majority of total catches. Predictably the catches obtained close to harbour appear higher when the 'Weather' is bad. The sites closest to the harbour rectangles $\mathrm{H} 1$ and $\mathrm{H} 2$ give the majority of catches while $\mathrm{H} 4$ (the farthest rectangle) is never visited at all when the weather is bad. Also, when fishers start a trip because others do, they tend to fish where their colleagues do.

\section{Random utility modelling}

The final multinomial logit model kept five variables that were statistically significant in explaining area choices (Table 3). The answers on "Fishing trip start" and on choosing "Fishing ground" appeared significant but the answers on "Fishing trip end" did not. The total catch that a vessel has achieved in the same rectangle in the previous month (i.e. Lag1_Catch) was significant. The temporal characteristics of the trip (month, year) also revealed explanatory power. The $\mathrm{R}^{2}$ indicated that the model explained $66 \%$ to $71 \%$ of the variation in area selection behaviour.
The predictive power of the model and the rectangle selection probabilities are shown in Table 4 and also illustrated in Figure 5. The real observations are compared with the results obtained by the model. The correct classification rate ranged from $52.4 \%$ to $71.3 \%$ for a specific rectangle, giving overall an adequate value of $62 \%$. The selection probabilities for each rectangle produced by the model appeared very close to the observed ones in both the overall results and the correctly classified cases (62\% of the cases).

Table 5 contains the statistically significant parameters of the multinomial logit model, omitting the non-significant ones. A negative sign of a parameter indicates lower probability for that case compared with the reference category. Before explaining a parameter, one must always take care of the relative reference categories. For example, the negative beta value of -2.733 at H2, in the "Harbour" choice of fishing ground indicates lower $\mathrm{H} 2$ selection probability than $\mathrm{H} 1$ (the reference rectangle category), but this happens only when closeness to "Harbour" dominates the fishing ground choice compared with "Own" reasons (the reference category for fishing ground). The total catch that a vessel has achieved in the same rectangle in the previous month (Lag1_Catch) is the only significant continuous variable in the current multinomial logit model. Table 5 shows the relative importance of Lag1_Catch for H2 and $\mathrm{H} 3$ only, i.e. the rectangles in which the main tar-
Choice of fishing trip start

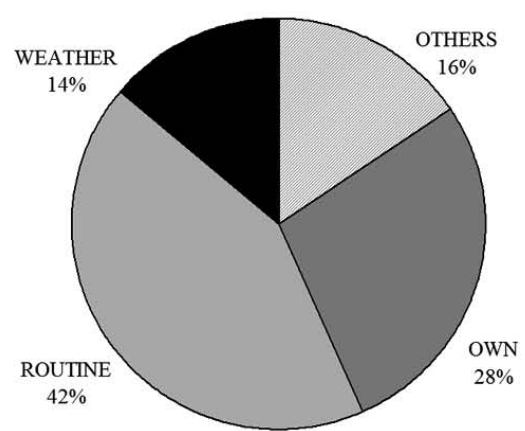

Choice of fishing trip end

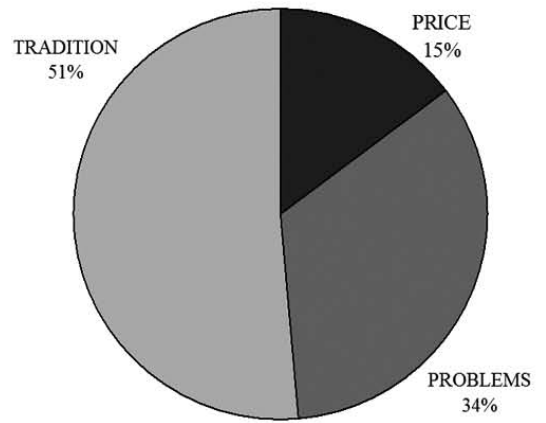

Choice of fishing ground

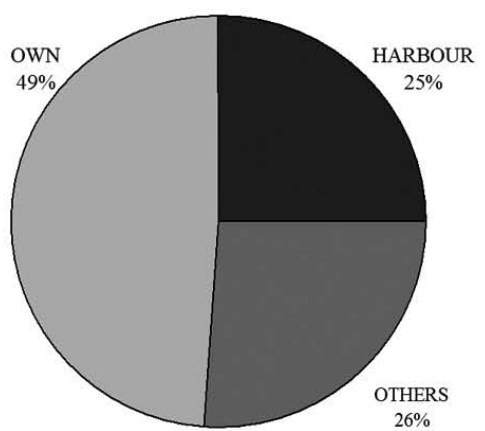

Fig. 3. - Responses in questionnaire choice selections: percentage of responses to choices of fishing trip start, fishing trip end and selected fishing ground. 

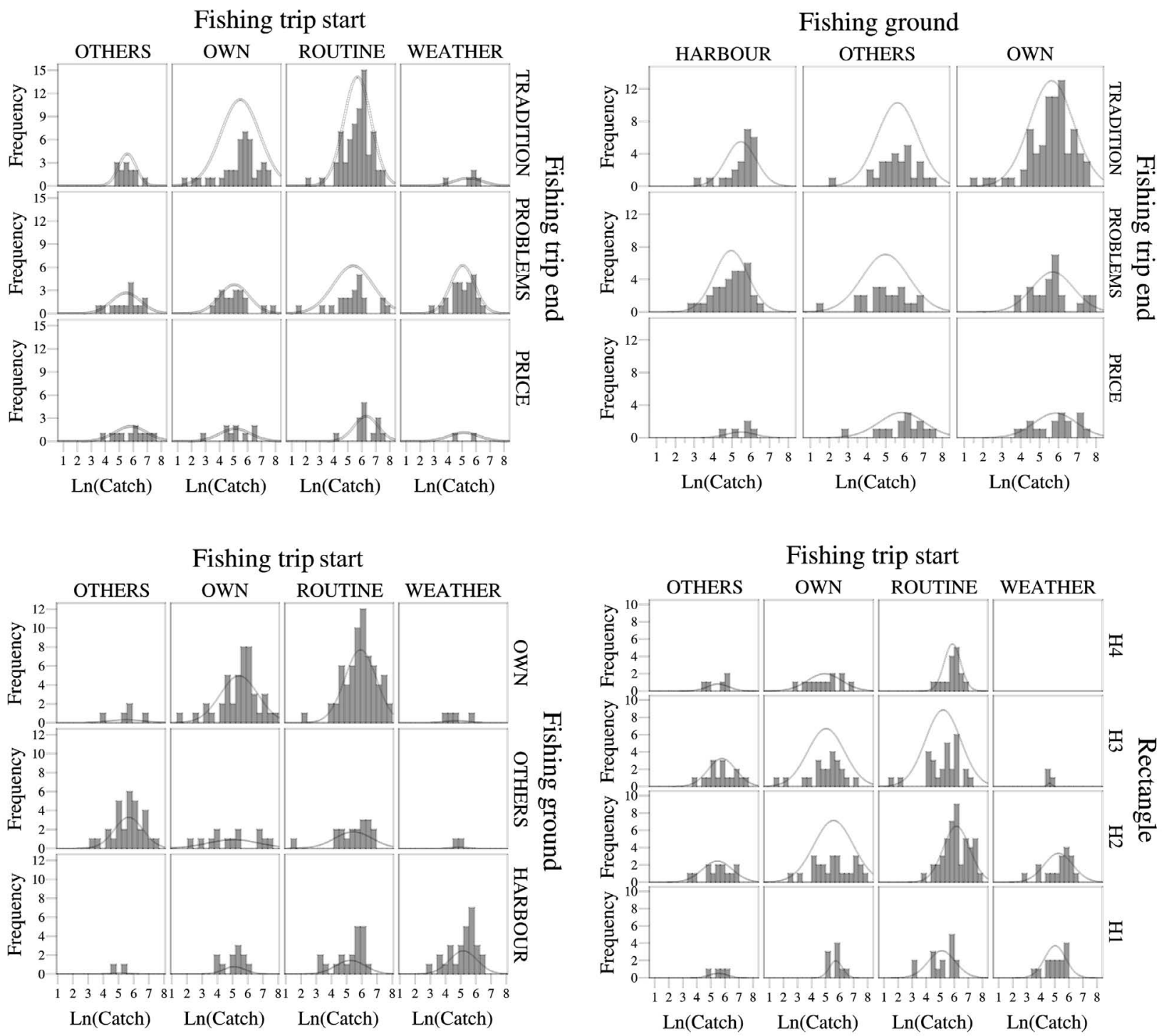

Fig. 4. - Purse seiner's total catch distribution (natural $\log$ ) by choice of fishing trip start, fishing trip end, fishing ground and rectangle combined.

Table 3. - Model fitting information and likelihood ratio tests of the multinomial logit RUM model. AIC, Akaike's Information Criterion; BIC, Schwarz's Bayesian Information Criterion; df, degrees of freedom; Sig. level of significance.

\begin{tabular}{|c|c|c|c|c|c|c|}
\hline \multirow[t]{2}{*}{$\begin{array}{l}\text { Model fitting info } \\
\text { Effect }\end{array}$} & \multicolumn{3}{|c|}{ Model fitting criteria } & \multicolumn{3}{|c|}{ Likelihood ratio tests } \\
\hline & AIC & $\mathrm{BIC}$ & -2 Log Likelihood & Chi-square & df & Sig. \\
\hline Intercept only & 603.725 & 614.229 & 597.725 & & & \\
\hline Final & 447.596 & 647.168 & 333.596 & 264.130 & 54 & 0.000 \\
\hline \multicolumn{7}{|c|}{ Pseudo R2: Cox and Snell $=0.660$, Negelkerke $=0.713$} \\
\hline \multicolumn{4}{|c|}{$\begin{array}{l}\text { Statistics related to the model parameters } \\
\text { Effect }\end{array}$} & \multicolumn{3}{|c|}{ Likelihood ratio tests for the model partial effects } \\
\hline & $\begin{array}{l}\text { AIC of re- } \\
\text { duced model }\end{array}$ & $\begin{array}{l}\text { BIC of re- } \\
\text { duced model }\end{array}$ & $\begin{array}{l}-2 \text { log likelihood of re- } \\
\text { duced model }\end{array}$ & Chi-square $^{(*)}$ & $\mathrm{df}$ & Sig. \\
\hline intercept & 447.596 & 647.168 & $333.596^{(\mathrm{a})}$ & .000 & 0 & \\
\hline lag1_Catch & 466.382 & 655.450 & 358.382 & 24.787 & 3 & 0.000 \\
\hline Fishing trip start & 449.160 & 617.220 & 353.160 & 19.564 & 9 & 0.021 \\
\hline Fishing ground & 545.350 & 723.914 & 443.350 & 109.754 & 6 & 0.000 \\
\hline Month & 488.827 & 604.369 & 422.827 & 89.231 & 24 & 0.000 \\
\hline Year & 449.060 & 606.616 & 359.060 & 25.464 & 12 & 0.013 \\
\hline
\end{tabular}

(*) This chi-square statistic is the difference in -2 log-likelihoods between the final model and a reduced model. The reduced model is formed by omitting an effect from the final model. The null hypothesis is that all parameters of that effect are 0 .

(a) This reduced model is equivalent to the final model because omitting the effect does not increase the degrees of freedom. 
Table 4. - Selection probabilities of the four rectangles $p(\mathrm{Hi})(\mathrm{i}=1,2,3,4)$ and classification results of the RUM model.

\begin{tabular}{|c|c|c|c|c|c|c|c|}
\hline \multirow[b]{2}{*}{ Rectangle } & \multicolumn{2}{|c|}{ Observed } & \multicolumn{4}{|c|}{ Predicted } & \multirow{2}{*}{$\%$ Correct classification } \\
\hline & $\mathrm{N}$ & $\mathrm{p}(\mathrm{Hi})$ & $\mathrm{N}$ & $p(\mathrm{Hi})$ & Correct $\mathrm{N}$ & Correct $\mathrm{p}(\mathrm{Hi})$ & \\
\hline H1 & 42 & 0.1714 & 35 & 0.1429 & 22 & 0.1447 & 52.4 \\
\hline $\mathrm{H} 2$ & 101 & 0.4122 & 108 & 0.4408 & 72 & 0.4737 & 71.3 \\
\hline H3 & 69 & 0.2816 & 76 & 0.3102 & 40 & 0.2632 & 58.0 \\
\hline $\mathrm{H} 4$ & 33 & 0.1347 & 26 & 0.1061 & 18 & 0.1184 & 54.5 \\
\hline Total & 245 & 1.0000 & 245 & 1.0000 & 152 & 1.0000 & 62.0 \\
\hline
\end{tabular}

get species, anchovy and sardine, dominate the catch. When a fisher selects $\mathrm{H} 1$ or $\mathrm{H} 4$ for fishing, the previous month's catch in these rectangles does not appear to have any significant effect.

\section{Sensitivity analysis}

The interpretation of the discrete choice parameters can be facilitated through sensitivity analysis graphs (Fig. 6). The sensitivity analysis of the model can reveal how the probability of selecting a particular fishing rectangle is affected by changing an input variable while keeping the others at a fixed value. Figure 6 shows examples investigating the monthly changes in rectangle selection probabilities for various choices of fishing ground, when the "Own" is the choice for fishing trip start. Under similar conditions (the same catches in the previous month for the year 2004) the

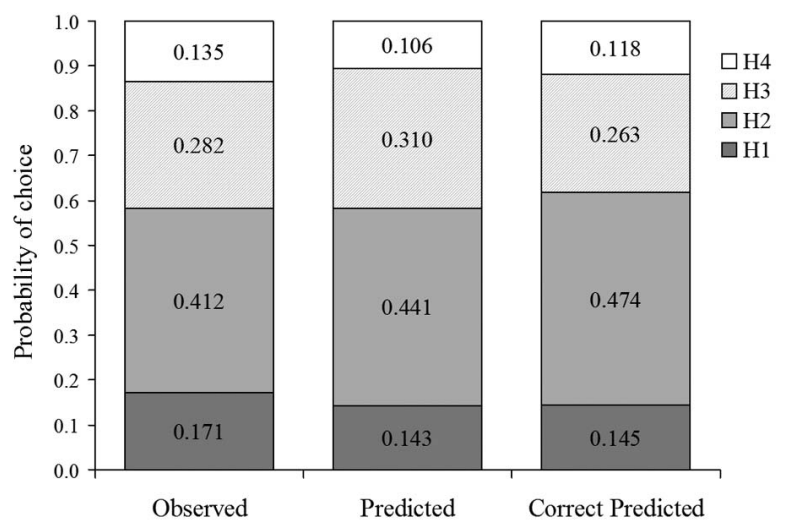

Fig. 5. - Selection probabilities of the four rectangles (H1 to H4): observed and predicted values from the multinomial logit RUM model.
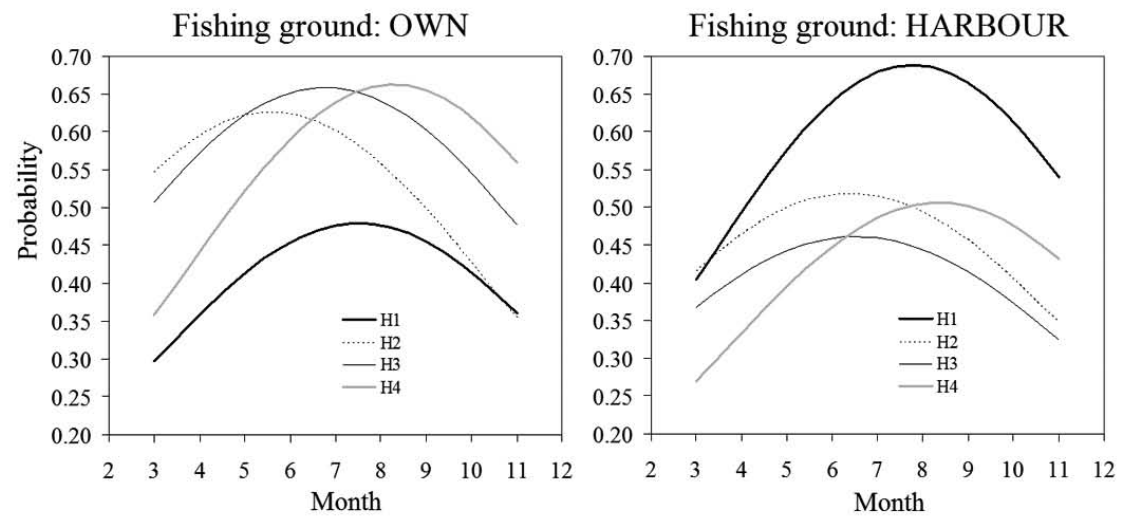

probability of choosing $\mathrm{H} 2$ rectangle when the fishing ground choice is "Own" has the earliest peak (Fig. 6, left), as it starts at the highest level early in the year (March to May), but diminishes after June, reaching the lowest value among rectangles at the end of the fishing period (November). An opposite behaviour appears in rectangle $\mathrm{H} 4$, which shows a peak after $\mathrm{Au}-$ gust. This behaviour is supported by the fact that $\mathrm{H} 2$ is the preferable area for the two main target species, anchovy and sardine, which dominate catches until June. When the choice criterion for visiting a fishing ground is its closeness to Harbour (Fig. 6 middle), although the pattern of rectangles' seasonal peaks exhibits a similar behaviour, it is obvious that the probability of choosing $\mathrm{H} 1$ prevails throughout the year, because it is the closest to the harbour.

\section{DISCUSSION}

All key international agreements adopted over the last two decades, including the 1995 FAO Code of Conduct for Responsible Fisheries, stress the need for the adoption of an ecosystem approach to fisheries (EAF). In response to these, in 2001, 57 countries issued the Reykjavik Declaration on Responsible Fisheries in the Marine Ecosystem, which included a declaration of their intention to work on incorporating ecosystem considerations into fisheries management. The 2002 Plan of Implementation of the World Summit on Sustainable Development called, among other things, for the application of the Reykjavik Declaration by 2010 as one of the steps essential for ensuring the sustainable development of the oceans (EC 2013).

Most aquatic ecosystems are unavoidably affected by fishery activities that involves a selective removal of part of the natural productivity for human subsist-

Fig. 6. - Examples of sensitivity analysis of the multinomial logit model. Smoothed lines of monthly changes in the probability of selecting a specific fishing rectangle ( $\mathrm{H} 1-\mathrm{H} 4)$ during the fishing season at different choices of fishing ground. Fishing start set to 'Own', year set to 2004, lag1_catch set to the mean value (193.4 kg per vessel-day). 
Table 5. - Parameter estimates of the multinomial logit model. Reference categories (having zero beta values) and non-significant parameters are omitted. The reference categories were H1 for rectangle, 'Weather' for fishing trip start, 'Own' for fishing ground, November for month and 2004 for year. B, parameter value; SE, standard error; Wald: Wald statistic ( $\mathrm{W}=\mathrm{B}^{2} / \mathrm{SE}^{2}$ ), is used to assess the significance of coefficients (asymptotically distributed as a chi-square distribution); Sig. level of significance; Exp(B), the natural logarithm raised to the parameter value B.

\begin{tabular}{|c|c|c|c|c|c|c|}
\hline Rectangle & Variable & B & SE & Wald & Sig. & $\operatorname{Exp}(B)$ \\
\hline \multirow[t]{9}{*}{$\mathrm{H} 2$} & Intercept & 3.817 & 1.521 & 6.300 & 0.012 & \\
\hline & lag1_Catch & 0.003 & 0.001 & 6.194 & 0.013 & 1.003 \\
\hline & Fishing trip start $=[$ ROUTINE $]$ & -0.737 & 0.680 & 1.177 & 0.078 & 0.478 \\
\hline & Fishing ground $=[$ HARBOUR] & -2.733 & 0.734 & 13.849 & 0.000 & 0.065 \\
\hline & Fishing ground $=[$ OTHERS $]$ & -1.691 & 0.994 & 2.896 & 0.089 & 0.184 \\
\hline & Month=[6] & -1.456 & 1.428 & 1.040 & 0.083 & 0.233 \\
\hline & Month $=[7]$ & -1.374 & 1.325 & 1.075 & 0.039 & 0.253 \\
\hline & Month $=[8]$ & -1.639 & 1.375 & 1.421 & 0.033 & 0.194 \\
\hline & Year $=[2001]$ & -1.109 & 0.825 & 1.807 & 0.079 & 0.330 \\
\hline \multirow[t]{4}{*}{$\overline{\mathrm{H} 3}$} & lag1_Catch & 0.002 & 0.001 & 1.067 & 0.032 & 1.002 \\
\hline & Fishing trip start $=[\mathrm{OWN}]$ & 1.684 & 1.473 & 1.307 & 0.053 & 5.386 \\
\hline & Year $=[2001]$ & -1.735 & 0.947 & 3.353 & 0.067 & 0.176 \\
\hline & Year $=[2002]$ & -1.063 & 0.964 & 1.216 & 0.070 & 0.345 \\
\hline \multirow[t]{8}{*}{$\overline{\mathrm{H} 4}$} & Fishing trip start $=[$ OTHERS $]$ & 16.722 & 1.438 & 135.240 & 0.000 & $1.8 \mathrm{E}+07$ \\
\hline & Fishing trip start $=[\mathrm{OWN}]$ & 20.006 & 0.958 & 436.200 & 0.000 & $4.9 \mathrm{E}+08$ \\
\hline & Fishing ground $=[$ OTHERS $]$ & 2.144 & 1.226 & 3.058 & 0.080 & 8.534 \\
\hline & Month $=[4]$ & -5.926 & 1.763 & 2.020 & 0.090 & 0.003 \\
\hline & Month $=[5]$ & -20.908 & 3.678 & 230.760 & 0.059 & $8.3 \mathrm{E}-10$ \\
\hline & Month $=[10]$ & -17.841 & 3.516 & 310.040 & 0.096 & $1.8 \mathrm{E}-08$ \\
\hline & Year $=[2000]$ & 2.597 & 1.409 & 3.397 & 0.065 & 13.425 \\
\hline & Year $=[2001]$ & -1.649 & 1.260 & 1.712 & 0.091 & 0.192 \\
\hline
\end{tabular}

ence, economic returns and development. However, undesirable fishing practices in some cases, such as overfishing and use of destructive methods, are unduly affecting these precious ecosystems, calling for urgent corrective action (FAO 2003). Here, we used an RUM approach to understand the main attributes that influence the fishing area choice made by Greek fishers within the discrete choice framework. The model explained fishers' behaviour adequately, combining subjective choice selections (such as trip start and fishing ground) and objective variables (month, year) along with past experience (expressed in previous month's catches). It was found that fishers would always seek to increase their profits by moving to the more profitable grounds. This finding will dictate their response to a likely implementation of an MPA under the EAF in the region or a spatiotemporal fishing ban on speciessensitive fishing grounds, i.e. spawning and nursery areas. The abundance in the different sub-areas and the resulting seasonal distribution of the fleet is to some extent related to the life histories of the target species, prey availability and prevailing oceanographic conditions in the area. For example, the Thermaikos Gulf is a semi-enclosed area characterized by zooplankton-rich waters (Zervakis and Georgopoulos 2002). The fresh water discharge of important rivers and the reduced offshore dispersal contributes to plankton retention. As a result, the most important spawning ground for anchovy and sardine in the area is located in the western part of the Thermaikos Gulf near the mouths of a series of rivers (i.e. the western part of rectangle $\mathrm{H} 1$ ). As fishers make decisions on the spatial location of operations on the basis of past catch rates, the observed high catch rates and the closeness of sub-area $\mathrm{H} 1$ to the fishing port could partly explain their choices. Reduced fuel costs, early landings and better sell prices in the market are additional benefits that may further explain such a choice.

The fisher's previous experience or knowledge, in terms of total catches in a given rectangle irrespective of their species composition (no species-specific catches appeared significant at any lag level), was also an important modulator of their effective fishing strategy. This is in agreement with results of previous studies reporting fishers choosing an area based on habitual past effort/tradition (Hutton et al. 2004, Tidd et al. 2012).

The technical characteristics of a vessel, such as the tonnage, horsepower and vessel length, were not significant, most likely because of the small variability in their values in the purse seine fleet examined. In the present work the proximity of the fishing grounds to the landing port restrained the location of the rectangles from becoming a factor that influences fishers' decisions. However, this could have been the case if the fishing grounds were located in distant areas. For example, Prellezo et al. (2009) observed that larger vessels had a higher probability of harvesting more remote areas. Mardle et al. (2006) also reported vessel age and size to be important modulators of fishers' decisions.

Other studied input variables, such as value and prices of the previous catch, did not improve the model, presumably because of their correlation with the volume of previous catch. The price of the different species did not seem to be important in the specific fishery. This is probably due to the similar market prices that the main target species, anchovy and sardine, have in the study area (Maravelias and Tsitsika 2008). Other studies have reported that fishers' tactics appeared to be based on past expected revenue of target species such as plaice (Hutton et al. 2004, Tidd et al. 2011) and sole (Tidd et al. 2012). In these areas and fisheries there are substantial differences between the market prices of the various target species.

Despite the limited amount of inputs, the RUM's classification performance was satisfactory. The estimated selection probability of each rectangle was very close to the observed one, thus enabling good predictions to be made. One of the key findings from this study is that the utility of fishing in a location (a given 
fishing area) depends on previous success measured as high catch rates, as well as previous experience, in this case a measure of past fishing practice monthly and annually (the effort allocation variable; Hutton et al. 2004, Tidd et al. 2012).

The results of a CREAM paper (Sartor et al., 2014) suggest that knowledge of fisheries characterization, stocks and habitats is relatively high in the Mediterranean Sea. By contrast, information on the management process and socioeconomic aspects of fisheries is relatively poor. The sustainable exploitation of marine living resources (including fisheries) and conservation of natural resources has been a top priority in the agenda of international organizations and States during the last two decades (for instance UNEP/MAP 2012, United Nations 2002), and the over-exploitation of stocks and impact of fishing activities on the environment has led to widespread demands for sustainable and responsible exploitation of stocks (for instance, the Marine Strategy Framework Directive 2008). The present study provided direct evidence on the role that the fishers' behaviour could play in understanding the way the industry will respond to changes in the resource, market conditions and management measures, and could thus help to define the research needs to implement an EAF in the eastern Mediterranean Sea and facilitate management advice. For example, the current analysis may prove useful in exploring alternative fisheries management scenarios under the EAF by testing the effects that the introduction of a technical measure could have (e.g. a closed area, an MPA or an extension/reduction of fishing season) in fishing effort reallocation and thus on resource sustainability.

\section{REFERENCES}

Andersen B.S., Vermard Y., Ulrich C., Hutton T., Poos J.J. 2010. Challenges in integrating short-term behaviour in a mixedfishery Management Strategies Evaluation frame: a case study of the North Sea flatfish fishery. Fish. Res. 102: 26-40. http://dx.doi.org/10.1016/j.fishres.2009.10.004

Cox D.R., Snell E.J. 1989. The Analysis of Binary Data. Chapman \& Hall, London, 236 pp.

European Commission (EC). 2013. Agriculture, forestry and fisheries statistics. Luxembourg, Publications Office of the European Union, 249 pp. http://dx.doi.org/10.2785/45595

FAO. 2003. The ecosystem approach to fisheries. FAO Technical Guidelines for Responsible Fisheries, No. 4 (Suppl. 2). FAO Fisheries Department, Rome, 112 pp.

Gordon H.S. 1954. The economic theory of a common property resource: the fishery. J. Polit. Econ. 62: 124-142. http://dx.doi.org/10.1086/257497

Greene W. 2000. Econometric Analysis. Prentice-Hall, New Jersey, 1004 pp.

Hilborn R., Orensanz J.M., Parma A.M. 2005. Institutions, incentives and the future of fisheries. Phil. Trans. Roy. Soc. B Biol. Sci. 360: 47-57.

Hutton T., Mardle S., Pascoe S., Clark R.A. 2004. Modelling fishing location choice within mixed fisheries: English North Sea beam trawlers in 2000 and 2001. ICES J. Mar. Sci. 61: 1443-1452. http://dx.doi.org/10.1016/j.icesjms.2004.08.016
Maravelias C.D., Tsitsika E.V. 2008. Economic efficiency analysis and fleet capacity assessment in Mediterranean fisheries. Fish. Res. 93: 85-91. http://dx.doi.org/10.1016/j.fishres.2008.02.013

Maravelias C.D., Damalas D., Ulrich C., Katsanevakis S., Hoff A. 2011. Multispecies fisheries management in the Mediterranean Sea: application of the Fcube methodology. Fish. Manag. Ecol. 19: 189-199. http://dx.doi.org/10.1111/j.1365-2400.2011.00801.x

Mardle S., Thebaud O., Guyader O., Hutton T., Prellezo R., Travers M. 2006. Empirical analysis of fishing fleet dynamics: entry, stay and exit choices in selected EU fisheries. 13th International Conference of the International Institute of Fisheries Economics and Trade (IIFET), Portsmouth, UK, 11-14 July 2006.

Marine Strategy Framework Directive. 2008. Directive 2008/56 of the European Parliament and of the Council of 17 June 2008 establishing a framework for community action in the field of marine environmental policy (Marine Strategy Framework Directive). Official Journal of the European Union, 25.06.2008.

McFadden D. 1973. Conditional logit analysis of qualitative choice behaviour. In: P. Zarembka (ed.), Frontiers in Econometrics. Academic Press, pp. 105-142.

Pradham N., Leung P. 2004. Modelling trip choice behaviour of the longline fishers in Hawaii. Fish. Res. 68: 209-224. http://dx.doi.org/10.1016/j.fishres.2003.12.006

Prellezo R., Lazkano I., Santurtún M., Iriondo A. 2009. A qualitative and quantitative analysis of selection of fishing area by Basque trawlers. Fish. Res. 97: 24-31. http://dx.doi.org/10.1016/j.fishres.2008.12.015

R Development Core Team. 2008. R: A Language and Environment for Statistical Computing. R Foundation for Statistical Computing, Vienna, Austria, http://www.R-project.org

Rijnsdorp A.D., Dol W., Hoyer M., Pastoors M.A. 2000. Effects of fishing power and competitive interactions among vessels on the effort allocation on the trip level of the Dutch beam trawl fleet. ICES J Mar Sci. 57: 927-937. http://dx.doi.org/10.1006/jmsc.2000.0580

Sartor P., Colloca F., Maravelias C.D., Maynou F., CREAM Partners. 2014. Critical assessment of the current understanding/ knowledge towards the framework of Ecosystem Approach of Fisheries in Mediterranean and Black Sea. Sci. Mar. 78S1: 19-27. http://dx.doi.org/10.3989/scimar.04021.17B

Smith M., Wilen J. 2003. Economic impacts of marine reserves: the importance of spatial behaviour. J. Env. Econ. Manag. 46: 183-206. http://dx.doi.org/10.1016/S0095-0696(03)00024-X

Smith M.D., Sanchirico J.N., Wilen J.E. 2009. The economics of spatial-dynamic processes: applications to renewable resources. J. Env. Res. Econ. 57: 104-121.

SPSS. 2003. SPSS Regression Models 12.0. SPSS Inc. Chicago, 71 pp.

Tidd A.N., Hutton T., Kell L.T., Padda G. 2011. Exit and entry of fishing vessels: an evaluation of factors affecting investment decisions in the North Sea English beam trawl fleet. ICES J. Mar. Sci. 68: 961-971. http://dx.doi.org/10.1093/icesjms/fsr015

Tidd A.N., Hutton T., Kell L.T., Blanchard J.L. 2012. Dynamic prediction of effort reallocation in mixed fisheries. Fish. Res. 125-126: 243-253. http://dx.doi.org/10.1016/j.fishres.2012.03.004

UNEP/MAP. 2012. State of the Mediterranean marine and coastal environment. Mediterranean Action Plan, Athens, 96 pp.

United Nations. 2002. Plan of Implementation of the World Summit on Sustainable Development. Retrieved from http://www. un.org/esa/sustdev/documents/WSSD_POI_PD/English/ WSSD_PlanImpl.pdf (accessed November 2013)

Wilen J.E., Smith M.D., Lockwood D., Botsford F.W. 2002. Avoiding surprises: incorporating fisherman behavior into management models. Bull. Mar. Sci. 70: 553-575.

Zervakis V, Georgopoulos D. 2002. Hydrology and circulation in the North Aegean (eastern Mediterranean) throughout 1997 and 1998. Med. Mar. Sci. 3: 5-19. 